\title{
Photosynthate partitioning in cultured marine phytoplankton: metabolic patterns in a marine diatom under constant and variable light intensities*
}

\author{
Gary L. Hitchcock ${ }^{1 * *}$, Joel C. Goldman ${ }^{2} \&$ Mark R. Dennett ${ }^{2}$ \\ ${ }^{1}$ Graduate School of Oceanography, University of Rhode Island, Narragansett, Rhode Island 02882-1197, USA. \\ ${ }^{2}$ Woods Hole Oceanographic Institution Woods Hole, Massachusetts 02543, USA
}

\begin{abstract}
Exponential phase cultures of the marine diatom Chaetoceros simplex (clone Bbsm) were cultured at $20^{\circ} \mathrm{C}$ and $636 \mu \mathrm{E} \mathrm{m}^{-2} \mathrm{~s}^{-1}$ to determine the rates at which photosynthesis and partitioning of carbon were altered in response to short-term fluctuations in light intensity. Carbon-specific uptake rates equalled cell specific growth rates for a minimum of $3 \mathrm{~h}$ at high light intensity $\left(636 \mu \mathrm{E} \mathrm{m}^{-2} \mathrm{~s}^{-1}\right)$. Low molecular weight (LMW) compounds were linearly labelled for up to $4 \mathrm{~h}$ under constant high light and accounted for nearly $70 \%$ of total ${ }^{14} \mathrm{C}$ fixed. Chloroform-soluble (lipid) and TCA-soluble (polysaccharide) fractions were uniformly labelled for only $2 \mathrm{~h}$, accounting for 9 to $15 \%$ of total ${ }^{14} \mathrm{C}$ fixed. Under low light intensity $\left(30 \mu \mathrm{E} \mathrm{m}^{-2} \mathrm{~s}^{-1}\right)$, the proportion of ${ }^{14} \mathrm{C}$ decreased in the $\mathrm{LMW}$, chloroform-soluble and TCA-soluble fractions, but increased in particulate materials relative to that occurring at high light. There was an increase in the carbon fixation rates of LMW, chloroform-soluble, and particulate fractions when these cells were re-exposed to high light; carbon partitioning into the TCA-soluble fraction was initially suppressed, but recovered within 30 to $60 \mathrm{~min}$. After $2 \mathrm{~h}$ of alternating $30 \mathrm{~min}$ exposures to high and low light, cells lost the ability to maintain a carbon fixation rate at $636 \mu \mathrm{E} \mathrm{m}^{-2} \mathrm{~s}^{-1}$ equivalent to that found in control cultures. Carbon fixation into LMW, chloroform-soluble, and TCAsoluble fractions under fluctuating irradiance occurred only at high light, while protein labeling was unaffected. Based on these metabolic patterns, it appears that short-term (15 to $30 \mathrm{~min}$ ) light fluctuations in situ may have a major influence on the pattern of carbon partitioning in marine phytoplankton.
\end{abstract}

\section{INTRODUCTION}

There has been a growing appreciation within the past few years that short-term fluctuations in light can have a major impact on primary production in the sea (Marra 1978, Marra \& Heinemann 1982). For example, fluctuations in the in situ light field to which a phytoplankton cell is exposed can vary from milliseconds to months (Falkowski 1984). Based on recent estimates, it appears that phytoplankton in the sea can be transported from the surface to depths of tens of meters within $30 \mathrm{~min}$ (see Denman and Gargett 1983). A

\footnotetext{
- Contribution No. 5733 from the Woods Hole Oceanographic Institution

- Present address: Nova University Oceanographic Center, 8000 N. Ocean Drive, Dania, Florida 33004, USA
}

phytoplankton cell could, therefore, experience intensities varying from full to a few \% of surface incident light during a $30 \mathrm{~min}$ 'cycle' when stationed within a turbulent eddy or Langmuir cell.

The frequencies of light fluctuations which affect photosynthesis range from several cycles $\mathrm{s}^{-1}$ (Walsh \& Legendre 1983) to cycles $\min ^{-1}$ (Marra \& Heinemann 1982, Savidge 1980) and $h^{-1}$ (Gallegos et al. 1982). Carbon fixation under fluctuating light sometimes is greater than under constant light (Marra 1978), but the inportance of this effect under conditions in situ has been questioned (Falkowski \& Wirick 1981). Although photosynthetic responses to fluctuating light and physiological mechanisms regulating these responses are well-documented (see Prezelin 1981, Marra \& Heinemann 1982, Falkowski 1984), the partitioning of photosynthate between different classes of compounds 
under variable light conditions has not been investigated. Most studies of photosynthate partitioning in marine phytoplankton have been conducted under constant light intensities, or with samples incubated at a constant isolume in the euphotic zone. We have, therefore, compared photosynthate partitioning in the marine diatom Chaetoceros simplex under constant and variable light intensities to characterize the flow of carbon into major biochemical components.

\section{METHODS}

Culture methods. Batch cultures of Chaetoceros simplex (clone Bbsm) first were grown in artificial seawater (Goldman \& McCarthy 1978) enriched with 200 $\mu \mathrm{g}$-at $\mathrm{l}^{-1} \mathrm{NH}_{4}^{+}, 20 \mu \mathrm{g}$-at $\mathrm{l}^{-1} \mathrm{PO}_{4}^{-3}, 200 \mu \mathrm{g}$-at $\mathrm{l}^{-1} \mathrm{Si}$, and trace metals and vitamins at half the concentration in 'f' medium (Guillard \& Ryther 1962). Cultures were maintained in 0.51 vessels (see Goldman \& McCarthy 1978) and harvested for experiments when cells were in late exponential phase. Light intensity was maintained at $636 \mu \mathrm{E} \mathrm{m}^{-2} \mathrm{~s}^{-1}$ of PAR from cool-white bulbs. Light intensities were measured with a QSL-100 quantum scalar irradiance meter (Biospherical Instruments, Inc.). The $4 \pi$ collector was placed directly in the culture vessel filled with medium. Temperature was held at $20^{\circ} \mathrm{C}$ by circulating water from a regulated bath through glass jackets outside each vessel.

Two replicate series of experiments were performed, Expt 1 and Expt 2. To initiate an experiment, $50 \mathrm{ml}$ aliquots were transferred from the $0.5 \mathrm{l}$ culture vessel to several $250 \mathrm{ml}$ water-jacketed vessels. One aliquot was maintained at $636 \mu \mathrm{E} \mathrm{m}^{-2} \mathrm{~s}^{-1}$ as a control ('High Light'), while a second was exposed to alternating $30 \mathrm{~min}$ periods at 636 and $30 \mu \mathrm{E} \mathrm{m} \mathrm{m}^{-2} \mathrm{~s}^{-1}$ ('Alternating Light'). A third aliquot was kept at $30 \mu \mathrm{E} \mathrm{m}^{-2} \mathrm{~s}^{-1}$ ('Low Light') and then at intervals of $30 \mathrm{~min}$ (Expt 1) or $60 \mathrm{~min}$ (Expt 2) subsamples were placed at $636 \mu \mathrm{E} \mathrm{m} \mathrm{m}^{-2}$ $\mathrm{s}^{-1}$ for 30 to 60 min periods. In preliminary experiments a light intensity of $636 \mu \mathrm{E} \mathrm{m}^{-2} \mathrm{~s}^{-1}$ had been found to be saturating for growth. Light intensity was reduced to $30 \mu \mathrm{E} \mathrm{m}^{-2} \mathrm{~s}^{-1}$ with neutral density PVC screening.

Determination of growth rate and cell composition. The maximum specific growth rate $(\hat{\mu})$ was calculated for each intensity by daily measurement of optical density at $600 \mathrm{~nm}$ using a Bausch \& Lomb Spectronic 88 , or by cell counts at $100 \times$ with a Spencer Brightline hemacytometer. Maximum specific growth rates $(\hat{\mu})$ were estimated from the slope of the linear part of the curve of In absorbance (cell count) vs time. When an experiment was initiated, samples were taken for analyses of particulate carbon (PC) and nitrogen (PN) (Perkin Elmer 240 Elemental Analyzer), $\mathrm{NH}_{4}^{+}$(McCar- thy \& Kamykowski 1972) and dissolved inorganic carbon (Dohrmann PR-1 carbon analyzer).

Inorganic carbon uptake. Carbon-14 (as $\mathrm{H}^{14} \mathrm{CO}_{3}$ ) was added to the $50 \mathrm{ml}$ aliquots at a specific activity of $62 \mathrm{mCi} \mathrm{mmol}{ }^{-1}$. At intervals of 2 to $20 \mathrm{~min}, 0.5 \mathrm{ml}$ aliquots were removed from each vessel and pipetted into scintillation vials containing $2 \mathrm{ml}$ of $5 \%$ glacial acetic acid in EtOH. The vial contents were evaporated to dryness under a heat lamp. One sample was assayed for total ${ }^{14} \mathrm{C}$ by liquid scintillation counting and a second was sealed and stored at $-10^{\circ} \mathrm{C}$ for fractionation.

Specific carbon uptake rates $\left(\mu^{\prime}\right)$ were calculated from the expression:

$$
\left.\mu^{\prime}=1 / \text { time }\left[\ln \left(\mathrm{C}+\mathrm{C}_{0}\right) / \mathrm{C}_{0}\right)\right]
$$

where $\mathrm{C}_{0}=$ initial $\mathrm{PC}_{i} \mathrm{C}=$ total carbon fixed from ${ }^{14} \mathrm{C}$ uptake. Specific carbon uptake rates were also measured by following the increase in $\mathrm{PC}$ in the original growth vessel over the duration of the ${ }^{14} \mathrm{C}$ incubation to provide an independent measure of inorganic carbon fixation.

Fractionations were made (Expt 2 only) according to the method described by Li et al. (1980). The extraction scheme yields 4 fractions: methanol/water-soluble, chloroform-soluble, $5 \%$ TCA-soluble and particulate materials. These fractions are operationally defined as corresponding to low molecular weight (LMW), lipid, polysaccharide and protein materials, respectively, although the separation of polymers is not complete (Hitchcock 1983). The carbon content of each fraction was calculated with the assumption that the specific activity of each fraction equalled that of the medium; since there was no means of evaluating the rate or activity of polymer precursors, the carbon content of each fraction is only an approximation.

\section{RESULTS}

\section{Total inorganic carbon uptake}

High Light. Under constant irradiance of $636 \mu \mathrm{E} \mathrm{m}^{-2}$ $\mathrm{s}^{-1}$, total inorganic carbon fixation was virtually linear for 3 to $4 \mathrm{~h}$ in both replicate experiments (Fig. 1A, B). In both experiments the specific carbon uptake rate $\mu^{\prime}$ was virtually equal to the respective specific growth rate $\hat{\mu}$ over the initial (first $0.5 \mathrm{~h}$ ) segments of the incubations, even though there were slight differences in $\hat{\mu}$ in the 2 inoculum cultures: $\hat{\mu}$ and $\mu^{\prime}$ were respectively $0.067 \mathrm{~h}^{-1}$ and $0.073 \mathrm{~h}^{-1}$ in Expt 1 and $0.053 \mathrm{~h}^{-1}$ and $0.048 \mathrm{~h}^{-1}$ in Expt 2 (Table 1). Based on $210 \mathrm{~min}$ of continuous exposure to high light, $\mu^{\prime}$ in Expt 1 was sustained at $0.065 \mathrm{~h}^{-1}$, but in Expt 2 it dropped slightly to $0.044 \mathrm{~h}^{-1}$. The deviations from virtually linear car- 
Fig. 1. Chaetoceros simplex. Time course of carbon fixation from ${ }^{14} \mathrm{C}$ uptake $(O)$ and particulate carbon increase (.) in duplicate experiments. Incubations were at $30(\bullet)$ and $636(O) \mu \mathrm{E} \mathrm{m}^{-2} \mathrm{~s}^{-1}$. (A, B) High Light and Alternating Light experiments. (C, D) Low Light experiment: labelling at $30 \mu \mathrm{E} \mathrm{m} \mathrm{m}^{-2}$ $\mathrm{s}^{-1}$, and subsequent carbon fixation in aliquots tranferred to 636 $\mu \mathrm{E} \mathrm{m}^{-2} \mathrm{~s}^{-1}$. Arrows in $\mathrm{A}$ and $\mathrm{B}$ represent end of linear ${ }^{14} \mathrm{C}$ fixa-

tion under constant light

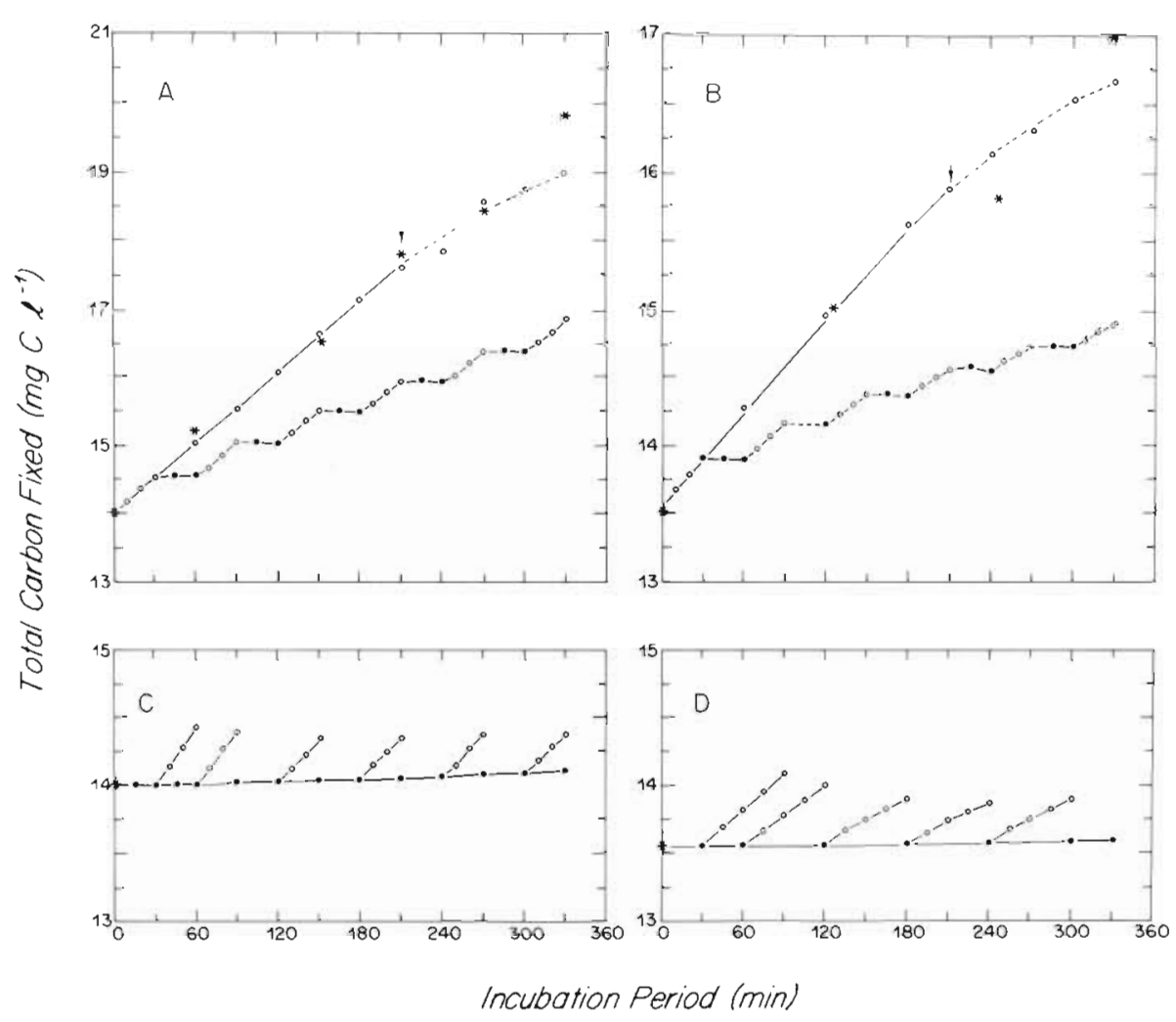

Table 1. Chaetoceros simplex. Summary of specific carbon uptake rates $(\mu)$ as a function of duration of variable light-dark regimes after growth in continuous light. 'Alternating Light': exposure to alternating high-low light for 330 min in 30 min intervals; 'Low Light': exposure to high light after prolonged exposure to low light

\begin{tabular}{|c|c|c|c|c|}
\hline & \multicolumn{2}{|c|}{ Alternating Light } & \multicolumn{2}{|c|}{ Low Light } \\
\hline & $\begin{array}{l}\text { High light intervals } \\
\text { during }{ }^{14} \mathrm{C} \\
\text { incubation (min) }\end{array}$ & $\begin{array}{c}\mu^{\prime} \\
\left(\mathrm{h}^{-1}\right)\end{array}$ & $\begin{array}{c}\text { High light intervals } \\
\text { during }{ }^{14} \mathrm{C} \\
\text { incubation (min) }\end{array}$ & $\begin{array}{c}\mu^{\prime} \\
\left(h^{-1}\right)\end{array}$ \\
\hline \multicolumn{5}{|l|}{ Expt 1} \\
\hline$\hat{\mu}=0.067 \mathrm{~h}^{-1}$ & $0-30$ & 0.073 & $0-30$ & 0.073 \\
\hline \multirow[t]{6}{*}{$\mu=0.065 \mathrm{~h}^{-1}$} & $60-90$ & 0.069 & $30-60$ & 0.063 \\
\hline & $120-150$ & 0.061 & $60-90$ & 0.057 \\
\hline & $180-210$ & 0.061 & $120-150$ & 0.049 \\
\hline & $240-270$ & 0.057 & $180-210$ & 0.043 \\
\hline & $300-330$ & 0.056 & $240-270$ & 0.046 \\
\hline & & & $300-330$ & 0.042 \\
\hline \multicolumn{5}{|l|}{ Expt 2} \\
\hline$\hat{\mu}=0.053 \mathrm{~h}^{-1}$ & $0-30$ & 0.048 & $0-30$ & 0.048 \\
\hline \multirow[t]{5}{*}{$\mu^{\prime}=0.044 \mathrm{~h}^{-1} \cdot$} & $60-90$ & 0.040 & $30-90$ & 0.036 \\
\hline & $120-150$ & 0.030 & $60-120$ & 0.029 \\
\hline & $180-210$ & 0.027 & $120-180$ & 0.022 \\
\hline & $240-270$ & 0.022 & $180-240$ & 0.019 \\
\hline & $300-330$ & 0.023 & $240-300$ & 0.020 \\
\hline $\begin{array}{l}\text { - Based on pre- } \\
\therefore \text { Based on expo }\end{array}$ & $\begin{array}{l}\text { wth measurements ur } \\
\text { lous high light for } 210\end{array}$ & $\begin{array}{l}\text { ontinu } \\
\text { during }\end{array}$ & & \\
\hline
\end{tabular}

bon uptake after 3 to 4 hours of labelling, and concomitant decreases in $\mu^{\prime}$ over time, appeared to occur as ambient ammonium concentrations (measured only in Expt 2) decreased below the limit of detection
(Table 2). In both experiments, increases in particulate carbon paralleled increases in ${ }^{14} \mathrm{C}$ (Fig. 1A, B).

Alternating Light. When cells were exposed to alternating intensities of 636 and $30 \mu \mathrm{E} \mathrm{m}^{-2} \mathrm{~s}^{-1}$ in $30 \mathrm{~min}$ 
Table 2. Chaetoceros simplex. Proportion of ${ }^{14} \mathrm{C}$ in labelled fractions incubated under constant or fluctuating irradiance (Expt 2)

\begin{tabular}{|c|c|c|c|c|c|c|}
\hline \multirow{2}{*}{$\begin{array}{l}\text { Irradiance } \\
\qquad\left(\mu \mathrm{E} \mathrm{m}^{-2} \mathrm{~s}^{-1}\right)\end{array}$} & \multirow{2}{*}{$\begin{array}{c}\text { Incubation } \\
\text { duration (min) }\end{array}$} & \multirow{2}{*}{$\begin{array}{c}\text { Residual } \mathrm{NH}_{4}^{+} \\
\left(\mu \text { g-at } \mathrm{I}^{-1}\right)\end{array}$} & \multicolumn{4}{|c|}{$\%{ }^{14} \mathrm{C}$ fixed } \\
\hline & & & LMW & Lipid & TCA-sol. & Part \\
\hline \multirow{4}{*}{$\begin{array}{l}\text { High Light } \\
\text { (636 constant) }\end{array}$} & & & & & & \\
\hline & 0 & 2.55 & - & - & - & - \\
\hline & 210 & 0.23 & 69 & 13 & 9 & 9 \\
\hline & 330 & 0.03 & 63 & 12 & 18 & 7 \\
\hline \multirow{2}{*}{$\begin{array}{l}\text { Alternating Light } \\
\quad(636 / 30)\end{array}$} & & & & & & \\
\hline & 330 & ND & 64 & 12 & 5 & 18 \\
\hline \multirow{3}{*}{$\begin{array}{l}\text { Low Light } \\
\qquad(30 \text { constant })\end{array}$} & & & & & & \\
\hline & 30 & ND & 22 & 11 & 45 & 22 \\
\hline & 330 & ND & 39 & 13 & 19 & 29 \\
\hline (Prolonged 636) & 300 & ND & 62 & 12 & 5 & 21 \\
\hline$N D=$ No data & & & & & & \\
\hline
\end{tabular}

intervals net carbon fixation occurred only at the higher light intensity. During each interval at low light there was a consistent but small net loss of carbon (Fig. $1 \mathrm{~A}, \mathrm{~B})$ with a corresponding negative $\mu^{\prime}$ of approximately $-0.002 h^{-1}$. This loss rate was observed repeatedly in subsequent experiments under alternating light periods for up to $5 \mathrm{~h}$ (data not shown). In Expt 1 the magnitude of $\mu^{\prime}$ decreased only slightly during successive intervals at high light: from $0.073 \mathrm{~h}^{-1} \mathrm{during}$ the first $30 \mathrm{~min}$ of high light exposure to $0.056 \mathrm{~h}^{-1}$ in the 6 th high light interval (330 min total incubation). There was, however, a greater decrease in $\mu$ at high light intensities in Expt 2, where $\mu$ decreased from $0.048 \mathrm{~h}^{-1}$ in the first $30 \mathrm{~min}$ interval to $0.023 \mathrm{~h}^{-1}$ in the 6 th interval of high light. This decrease in $\mu^{\prime}$ indicated a loss of recovery for potential carbon fixation when cells were re-exposed to saturating intensities.

Low Light. When cells were continuously incubated at low light $\left(30 \mu \mathrm{E} \mathrm{m} \mathrm{m}^{-2} \mathrm{~s}^{-1}\right.$ ) there was a small, but positive, net fixation of carbon in both experiments (Fig. 1C, D). These increases in fixed carbon correspond to low $\left(0.01\right.$ to $\left.0.02 \mathrm{~h}^{-1}\right)$, but positive, values of $\mu^{\prime}$. Following a prolonged exposure to low light, transfer to high light led to rapid increases in carbon fixation (Fig. 1C, D), although $\mu$ ' was slightly lower than when cells were exposed to alternating light regimes and there was at trend of decreasing $\mu$ during each successive transfer to high light (Table 1). Therefore, as the duration of exposure to low light increased there was a decrease in the potential to fix carbon when cells were re-exposed to high light.

\section{Patterns of photosynthate partitioning}

Patterms of photosynthate partitioning were directly related to incident light conditions.
High Light. Partitioning of inorganic carbon into the various fractions was approximately linear for $4 \mathrm{~h}$ under continuous and high $\left(636 \mu \mathrm{E} \mathrm{m}^{-2} \mathrm{~s}^{-1}\right)$ irradiation (Fig. 2A). Under these conditions, a major fraction of incorporated ${ }^{14} \mathrm{C}$ was recovered from LMW materials, (nearly $65 \%$ of the total ${ }^{14} \mathrm{C}$ fixed). The $\mathrm{CHCl}_{3}, \mathrm{TCA}$ soluble and particulate fractions each contained less than $20 \%$ of total ${ }^{14} \mathrm{C}$ fixed (Table 2). After the initial

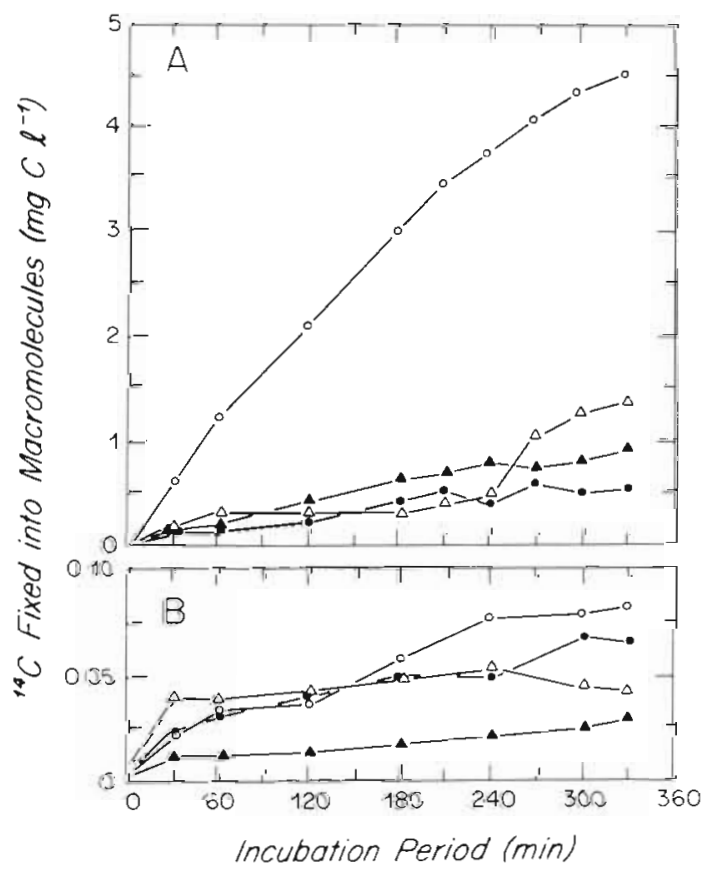

Fig. 2. Chaetoceros simplex. Time course of carbon partitioning into extracted fractions (Expt 2). Culture preconditioned at $636 \mu \mathrm{E} \mathrm{m}^{-2} \mathrm{~s}^{-1}$ and labelled at (A) $636 \mu \mathrm{E} \mathrm{m}^{-2} \mathrm{~s}^{-1}$ (High Light experiment) and (B) $30 \mu \mathrm{E} \mathrm{m} \mathrm{m}^{-2} \mathrm{~s}^{-1}$ (Low Light experiment). Carbon fixation into individual fractions: (0) low molecular weight; ( $\Delta$ chloroform-soluble; $(\Delta)$ TCA-soluble; $(\bullet)$ particulate 
$4 \mathrm{~h}$, the rate of ${ }^{14} \mathrm{C}$ fixation into TCA-soluble material increased (Fig. 2A). This change in the partitioning of ${ }^{14} \mathrm{C}$ corresponded to the period when ammonium in the culture appeared to be depleted (Table 2).

Alternating Light. Patterns of inorganic carbon partitioning under alternating light (30 min each at 636 and $30 \mu \mathrm{E} \mathrm{m}^{-2} \mathrm{~s}^{-1}$ ) differed from those observed under continuous illumination. Synthesis of the LMW, TCAsoluble and particulate materials was highest when cells were exposed to $636 \mu \mathrm{E} \mathrm{m}^{-2} \mathrm{~s}^{-1}$, whereas labelling of $\mathrm{CHCl}_{3}$-soluble material was rather erratic (Fig. 3). The ${ }^{14} \mathrm{C}$ within the LMW and TCA-soluble materials

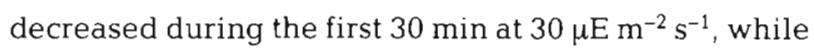

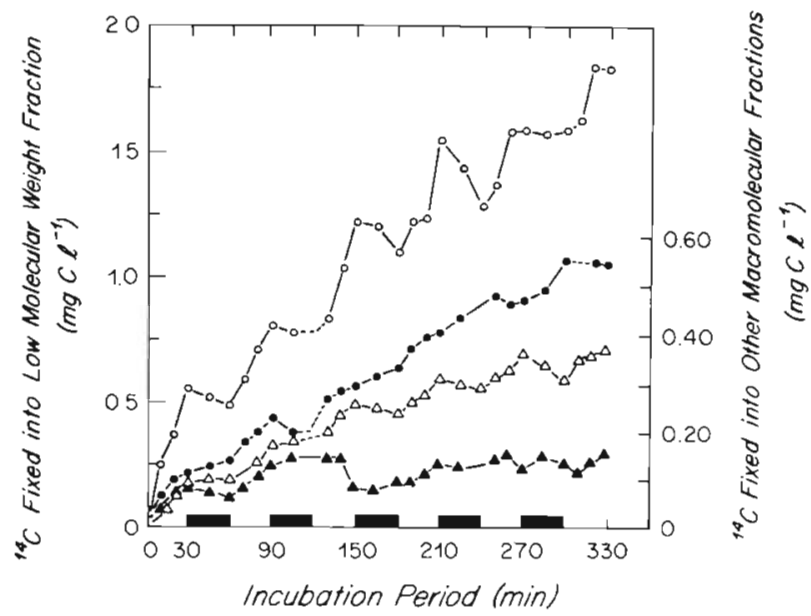

Fig. 3. Chaetoceros simplex. Alternating light experiment. Time course of carbon partitioning of ${ }^{14} \mathrm{C}$ into extracted fractions (Expt 2). Culture preconditioned at $636 \mu \mathrm{E} \mathrm{m}^{-2} \mathrm{~s}^{-1}$ and labelled at alternating $30 \mathrm{~min}$ periods at 636 and $30 \mu \mathrm{E} \mathrm{m} \mathrm{m}^{-2}$ $\mathrm{s}^{-1}$. Solid blocks represent exposure at $30 \mu \mathrm{E} \mathrm{m} \mathrm{m}^{-2} \mathrm{~s}^{-1}$. Symbols as in Fig. 2 that in the protein fraction increased. The ${ }^{14} \mathrm{C}$ activity of the LMW and $\mathrm{CHCl}_{3}$-soluble fractions subsequently decreased during each period at $30 \mu \mathrm{E} \mathrm{m}^{-2} \mathrm{~s}^{-1}$ (Fig. 3). Only in the particulate fraction did ${ }^{14} \mathrm{C}$ activity continue to increase during alternating periods of high and low irradiance. In comparison to the pattern found at continuous high light, the alternating light regime led to a $60 \%$ reduction of fixed ${ }^{14} \mathrm{C}$ in the TCA-soluble fraction, but a $157 \%$ increase (from $7 \%$ to $18 \%$ ) in the particulate fraction over the course of a 330 min incubation (Table 2).

Low Light. During the first $30 \mathrm{~min}$ of incubation under continuous low light $45 \%$ of ${ }^{14} \mathrm{C}$ incorporated went into the TCA-soluble fraction, $22 \%$ into each of the LMW and particulate fractions and only $11 \%$ into the $\mathrm{CHCl}_{3}$-soluble fraction (Table 2; Fig. 2B). The rate of ${ }^{14} \mathrm{C}$ incorporation into the TCA-soluble fraction slowed considerably with further incubation and even became negative after $240 \mathrm{~min}$. In contrast, ${ }^{14} \mathrm{C}$ labelling in both the LMW and particulate fractions, and to a lesser degree in the $\mathrm{CHCl}_{3}$ fraction, increased throughout the incubations so that by $330 \mathrm{~min} 39 \%$ of total ${ }^{14} \mathrm{C}$ fixed was in the LMW fraction, $29 \%$ in the particulate fraction, $13 \%$ in the $\mathrm{CHCl}_{3}$ fraction and only $19 \%$ in the TCA-soluble fraction (Table 2 ; Fig. 2B).

In cells maintained at low light and subsequently transferred to high light, labelled carbon primarily went into the LMW (Fig. $4 \mathrm{~A}$ ), $\mathrm{CHCl}_{3}$-soluble (Fig. $4 \mathrm{~B}$ ) and particulate fractions (Fig. $4 \mathrm{C}$ ), although the rate of net carbon synthesis in each fraction decreased during the successive high light periods (Table 2). TCA-soluble compounds were rapidly labelled during the first exposure to high light, but thereafter the pattern of ${ }^{14} \mathrm{C}$
Fig. 4. Chaetoceros simplex. Low Light experiment. Time course of carbon partitioning as ${ }^{14} \mathrm{C}$ into extracted fractions (Expt 2). Culture preconditioned at $636 \mu \mathrm{E} \mathrm{m} \mathrm{m}^{-2} \mathrm{~s}^{-1}$ and labelled at $30 \mu \mathrm{E} \mathrm{m} \mathrm{m}^{-2} \mathrm{~s}^{-1}(\bullet)$ with subsequent transfers to $636 \mu \mathrm{E} \mathrm{m}^{-2} \mathrm{~s}^{-1}(\mathrm{O})$ : (A) low molecular weight; (B) chloroform-soluble; (C) particulate; (D) TCA-soluble
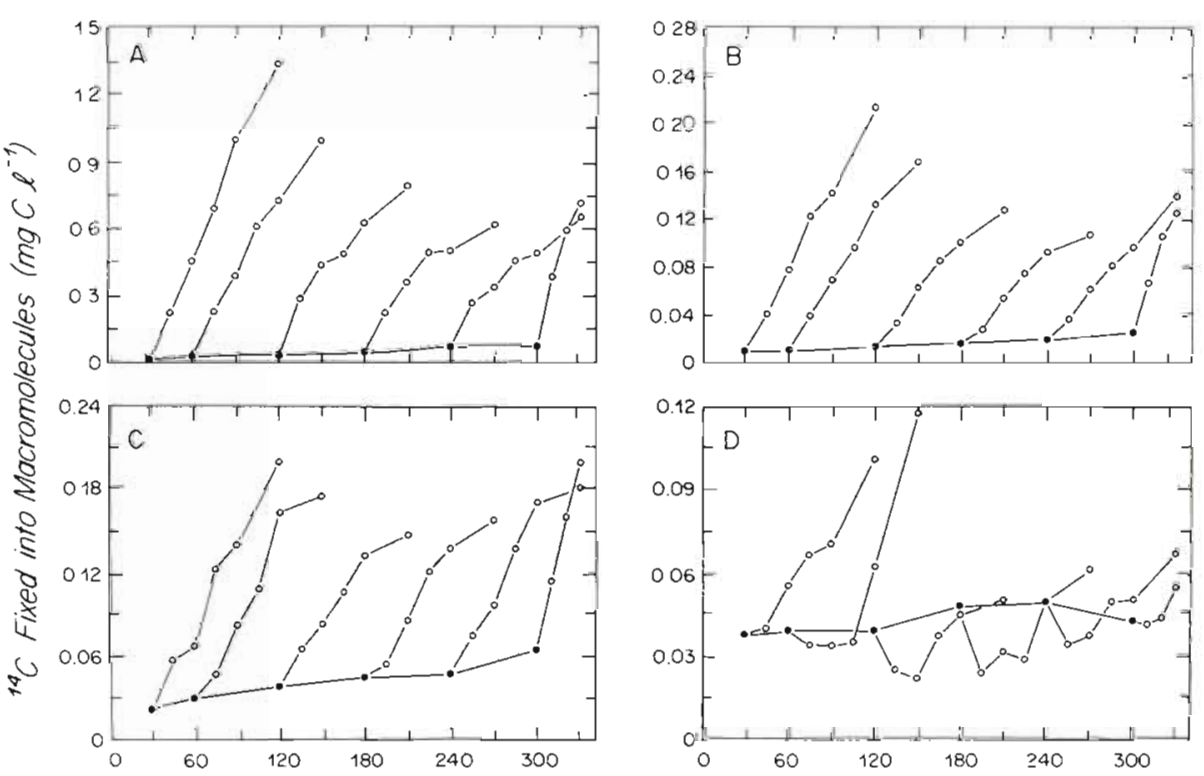
labelling of this material was erratic (Fig. 4D). By 300 min incubation, $62 \%$ of label was present in the LMW fraction, $12 \%$ in the $\mathrm{CHCl}_{3}$-soluble fraction, $21 \%$ in the particulate function, and only $5 \%$ in the TCAsoluble fraction (Table 2).

\section{DISCUSSION}

\section{Total carbon fixation rates}

Chaetoceros simplex (Bbsm) was selected for this study because in previous experiments it displayed short-term carbon-specific uptake rates $\left(\mu^{\prime}\right)$ that were virtually equal to specific growth rates $(\mu)$ under a variety of environmental conditions ( $\mathrm{Li} \&$ Goldman 1981, Goldman \& Dennett 1983). A close relation between $\mu$ and $\mu^{\prime}$ provides some assurance that the variability in $\mu$ was real, and not an artifact of culturing.

The photosynthetic patterns we observed in Chaetoceros simplex were in response to 'square wave' fluctuations in the light field. The alternating $30 \mathrm{~min}$ exposures to high and low intensities were of sufficient duration to provide accurate estimates of specific carbon uptake rates $\left(\mu^{\prime}\right)$ and carbon partitioning patterns. These exposure times approximate first order transit times of water parcels (and presumably of entrained phytoplankton) from the surface to depths on the order of $40 \mathrm{~m}$ when surface wind velocities are approximately $10 \mathrm{~m} \mathrm{~s}^{-1}$. Thus the carbon partitioning we observed in the laboratory may be representative of field conditions in which diatom populations are transported through Langmuir cells or turbulent eddies.

Specific carbon uptake rates $\left(\mu^{\prime}\right)$ of Chaetoceros simplex were nearly equivalent to corresponding cell growth rates during repeated transitions from low

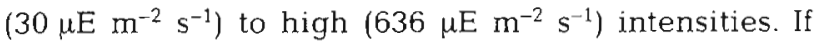
natural diatom populations exhibit a similar response, then rapid movement of cells through the mixed layer would have little impact on $\mu$, for total inorganic carbon fixation is, essentially, a function of total light received. In particular, cells entrained for long periods at low light would still retain the capacity to revert rapidly back to an earlier higher growth rate once more favorable light conditions prevailed. Marra \& Heineman (1982), in contrast, found that maximum rates of oxygen production in the diatom Lauderia borealis occurred before maximum light intensities were attained on days with extremely variable sunlight, while rates of $\mathrm{O}_{2}$ production on cloudy days showed a close correspondence with incident irradiance. A major difference, however, between their work and ours was that $\mathrm{O}_{2}$ production in $L$. borealis was measured at light variations with frequencies of $\leq 5$ cycles $\mathrm{s}^{-1}$, while ${ }^{14} \mathrm{C}$ fixation in $\mathrm{C}$. simplex was measured at only 2 cycles $h^{-1}$. The physiological mechanisms regulating $\mathrm{O}_{2}$ evolution at these higher frequencies of light variability (fluorescence yield reactions of electron carriers) are indirectly coupled to carbon fixation. The differences in sampling frequencies prevents a direct comparison of the responses between $C$. simplex and L. borealis. Walsh \& Legendre (1983), similarly, found that variations of 2 to 5 cycles $\mathrm{s}^{-1}$ increased carbon fixation in natural populations. However, it is clear from our results that $\mu$ of $C$ simplex varies as a direct function of ambient irradiance when light variations occur at frequencies of at least $2 \mathrm{~h}^{-1}$

\section{Photosynthate partitioning}

Specific patterns of inorganic carbon fixation observed in Chaetoceros simplex varied with the initial light intensity at which the cells were labelled. Cells cultured at $636 \mu \mathrm{E} \mathrm{m} \mathrm{m}^{-2} \mathrm{~s}^{-1}$ maintained a low, yet positive $\mu$ when initially transferred and labelled at $30 \mu \mathrm{E} \mathrm{m}^{-2} \mathrm{~s}^{-1}$ ('Low light' experiment). However, if cells were initially labelled at $636 \mu \mathrm{E} \mathrm{m}^{-2} \mathrm{~s}^{-1}$ for $30 \mathrm{~min}$ and then transferred to low light ('Alternating light' experiment), they maintained a small, negative $\mu$ '. The loss of fixed carbon at low light occurred in either the LMW or $\mathrm{CHCl}_{3}$-soluble fractions, but was most prevalent in LMW compounds. The decrease in cellular ${ }^{14} \mathrm{C}$ following transfer of cells from saturating to nearcompensating intensities was similar to the loss of ${ }^{14} \mathrm{C}$ observed in freshwater phytoplankton when they were initially labelled at a near-saturating intensity $(140 \mu \mathrm{E}$ $\mathrm{m}^{-2} \mathrm{~s}^{-1}$ ) and then transferred to the dark (Bidwell 1977). Bidwell (1977) hypothesized that the loss of ${ }^{14} \mathrm{C}$ in some freshwater species was due to the transfer of labelled photosynthate from the chloroplast to the cytoplasm where photosynthate was respired. If a similar metabolic response occurs in $C$. simplex, the export of recently-labelled materials from the chloroplasts mainly occurs when cells are transferred from high light. At $30 \mu \mathrm{E} \mathrm{m}^{-2} \mathrm{~s}^{-1}$ the catabolic needs for carbon in C. simplex may have exceeded the photosynthetic rate for a brief period, so a net loss of label occurred as labelled photosynthate was exported from the chloroplast into the cytoplasm and subsequently respired. This hypothesis deserves further study to document if recent photosynthate is principally exported to the cytoplasm when cells are exposed to near-compensating intensities.

The proportion of ${ }^{14} \mathrm{C}$ fixed into $\mathrm{LMW}$ compounds was reduced and that into proteins increased in Chaetoceros simplex incubated at low light relative to that at high light. The metabolic pattern observed in 
C. simplex is similar to that in natural populations, although polysaccharide materials generally account for a greater proportion of total ${ }^{14} \mathrm{C}$ fixed at intensities saturating photosynthesis (Morris 1981). The only obvious deviation from linear incorporation in our study was that the proportion of ${ }^{14} \mathrm{C}$ in TCA-soluble materials increased as $\mu$ declined in response to apparent nitrogen depletion when cells were exposed to high light after $240 \mathrm{~min}$. An increase in the proportion of ${ }^{14} \mathrm{C}$ fixed into TCA-soluble materials could reflect an increased production of 'reserve' polysaccharide which, at least in diatoms, increases in response to nitrogen limitation (Myklestad 1974). The increased synthesis of polysaccharide materials after $\mathrm{N}$ depletion at $240 \mathrm{~min}$ is, to our knowledge, the first demonstration of the time course of photosynthate partitioning in response to nutrient limitation. Given the rapid alteration in the pattern of labelling, time courses of photosynthate partitioning in response to nutrient additions may provide qualitative information on relative nutrient deficiency in natural populations.

The partitioning of ${ }^{14} \mathrm{C}$ into $\mathrm{LMW}$ materials was tightly coupled to irradiance. In cells initially labelled at high light the activity of the LMW fraction decreased following transfer to low light. The decrease in the proportion of ${ }^{14} \mathrm{C}$ fixed into the LMW materials can be attributed to catabolic processes (respiration), excretion, and the incorporation of LMW compounds into polymers such as proteins. The proportion of ${ }^{14} \mathrm{C}$ fixed in LMW compounds represented the majority of carbon fixed in cells intially labelled at low light and transferred to high light; at that time the specific carbon uptake exceeded the growth rate $\left(\mu^{\prime}>\mu\right)$. This pattern of carbon partitioning may not be unique to diatoms, for in the chlorophyte Chlorella similar 'bursts' of specific carbon uptake exceeding growth rate have been attributed to the temporary overflow of fixed carbon in storage products such as starch (Myers 1970).

The erratic yet continuous increase of ${ }^{14} \mathrm{C}$ in the particulate fraction was, most likely, due to a continued synthesis of proteins under fluctuating irradiance. Since protein production (e.g. Eppley et al. 1967. Hitchcock 1980) and ${ }^{14} \mathrm{C}$ labelling of the particulate fraction (Morris \& Skea 1978, Cuhel et al, 1984), continues in the dark at rates comparable to those in the light, the partitioning of ${ }^{14} \mathrm{C}$ into the particulate fraction would be expected to continue at a constant rate under a fluctuating light regime. From previous studies, as reviewed by Morris (1981), it appears that the capacity of phytoplankton to synthesize proteins is conserved under environmental stress; our observations with Chaetoceros simplex also indicate that the labelling of the protein fraction is 'conserved' during the short-term fluctuations in irradiance.

The partitioning of ${ }^{14} \mathrm{C}$ into 'storage materials' - polysaccharides and lipids - indicates the physiological role these compounds have under a fluctuating light regime. The activity of ${ }^{14} \mathrm{C}$ fixed into the lipid fraction increased and decreased under alternating periods of high and low light, respectively. A decrease in the activity of ${ }^{14} \mathrm{C}$ in the lipid fraction when cells were exposed to low light shows that these compounds provide carbon and energy for the cell at a nearcompensating light intensity. Furthermore, Chaetoceros simplex maintained its ability to synthesize lipids following transfer from low to high light as the incubation period at low light increased (Fig. 4B). Unlike the TCA-soluble compounds (polysaccharides), lipids were readily synthesized after a prolonged exposure to a subsaturating intensity.

The activity of ${ }^{14} \mathrm{C}$ in the TCA-soluble fraction, in contrast, did not increase at high light when cells were exposed to fluctuating irradiance. Although diatom reserve polysaccharides are synthesized in the light and respired in the dark (Handa 1969, Hitchcock 1980), there was no consistent synthesis or utilization of the TCA-soluble materials when cells of Chaetoceros simplex were incubated under alternating high-low irradiances of $30 \mathrm{~min}$ each. Furthermore, the loss of ${ }^{14} \mathrm{C}$ from TCA-soluble material in C. simplex following reexposure to high light after a prolonged incubation at low light (Fig. 4D), was surprising. Both responses indicate that $C$. simplex requires continued exposure to a high, or perhaps saturating, intensity to maintain an ability to synthesize polysaccharides.

In higher plants the synthetic mechanism for starch production is light-dependent (Champigny \& Bismuth 1976. Buchanan 1980); a continued synthesis of starch requires exposure to high light intensities to maintain activated enzymes. In Chaetoceros simplex the reduction of ${ }^{14} \mathrm{C}$ activity within the TCA-soluble fraction after re-exposure to high light (Fig. 4D) may have resulted from a catabolic demand for polysaccharides (respiration, carbon for synthesis of other compounds) which exceeded the rate of synthesis rates as synthesis mechanism(s) were being re-activated. The interdependence of light intensity and exposure period on the rate of synthesis and utilization of reserve polysaccharides during transfer from one light intensity to another is obviously poorly understood. Measurements of glucan synthease activity and exo- $(\beta-1,3)$-glucanase activity (Myklestad et al. 1982) during prolonged incubation at subsaturating intensities are necessary to confirm if catabolic activity exceeds synthetic capacity under fluctuating light regimes. From previous studies it appears that algae preferentially utilize reserve carbohydrates before lipids (Handa 1969, Li \& Harrison 1982). If there is a requirement for light-activation of polysaccharide synthesis, however, then lipids could also have an important function in providing energy in 
an environment with a rapidly-varying light field. In future studies the physiological role of reserve lipids and polysaccharides in providing energy and carbon for continued protein synthesis should be examined under fluctuating light conditions similar to those which phytoplankton cells may experience in the ocean.

Acknowledgements. This study was supported by NSF Grants OCE 80-17272 (GLH) and OCE-8219578 (JCG).

\section{LITERATURE CITED}

Bidwell, R. G. S. (1977). Photosynthesis and light and dark respiration in freshwater algae. Can. J. Bot. 55: 809-818

Buchanan, B. B. (1980). Role of light in the regulation of chloroplast enzymes. A. Rev. Pl. Physiol. 31: 341-374

Champigny, M., Bismuth, E. (1976). Role of photosynthetic electron transfer in light activation of Calvin cycle enzymes. Physiologia Pl. 36: 95-100

Cuhel, R. L., Ortner, P. B., Lean, D. R. S. (1984). Night synthesis of protein by algae. Limnol. Oceanogr. 29 $745-762$

Denman, K. L., Gargett, A. E. (1983). Time and space scales of vertical mixing and advection of phytoplankton in the upper ocean. Limnol. Oceanogr. 28: 801-815

Eppley, R., Holmes, R. W., Paasche, E. (1967). Periodicity in cell division and physiological behavior of Ditylum brightwellii, a marine planktonic diatom, during lightdark cycles. Arch. Mikrobiol. 56: 305-323

Falkowski, P. G. (1984). Physiological responses of phytoplankton to natural light regimes. J. Plankton Res. 6: 295-307

Falkowski, P. G., Wirick, C. D. (1981). A simulation model of the effects of vertical mixing on primary productivity. Mar. Biol. 65: 69-75

Gallegos, C. L., Platt, T, Harrison, W. G., Irwin, B. (1982). Photosynthetic parameters of Arctic marine phytoplankton: vertical variations and time scales of adaptation. Limnol. Oceanogr. 27: 698-708

Goldman, J. C., Dennett, M. R. (1983). Effect of photoinhibition during bottle incubations on the measurement of seasonal primary production in a shallow coastal water. Mar. Ecol. Prog. Ser. 15: 169-180

Goldman, J. C., McCarthy, J. J. (1978). Steady state growth and ammonium uptake of a fast-growing marine diatom. Limnol. Oceanogr. 23: 695-730

Guillard, R. R. L., Ryther, J. H. (1962). Studies of marine planktonic diatoms. I. Cyclotella nana Hustedt and Detonula confervacea (Cleve) Gran. Can. J. Microbiol. 8: 229-239
Handa, N. (1969). Carbohydrate metabolism in the marine diatom Skeletonema costatum. Mar. Biol. 4: 208-214

Hitchcock, G. L. (1980). Diel variation in chlorophyll a, carbohydrate and protein content of the marine diatom Skeletonema costatum. Mar. Biol. 57: 271-278

Hitchcock, G. L. (1983). Photosynthate partitioning in cultured marine phytoplankton. I. Dinoflagellates. J. exp. mar. Biol. Ecol. 69: 21-36

Li, W. K. W., Glover, H. E., Morris, I. (1980). Physiology of carbon assimilation by Oscillatoria thiebautii in the Caribbean Sea. Limnol Oceanogr. 25: 447-456

Li, W. K. W., Goldman, J. C. (1981). Problems in estimating growth rates of marine phytoplankton from short-term ${ }^{14} \mathrm{C}$ assays. Microb. Ecol. 7: 113-121

Li, W. K. W., Harrison, W. G. (1982). Carbon flow into the end products of photosynthesis in short and long incubations of a natural phytoplankton population. Mar. Biol. 72: $175-182$

Marra, J. (1978). Phytoplankton photosynthetic response to vertical movement in a mixed layer. Mar. Biol. 46: 203-208

Marra, J., Heinemann, K. (1982). Photosynthesis response by phytoplankton to sunlight variability. Limnol. Oceanogr. 27: 1141-1153

McCarthy, J. J., Kamykowski, D. (1972). Urea and other nitrogenous nutrients in La Jolla Bay during February, March and April, 1970. Fish. Bull. U.S. 70: 1261-1274

Morris, I. (1981). Photosynthesis products, physiological state and phytoplankton growth. In: Platt, T. (ed.) Physiological bases of phytoplankton ecology. Can. Bull. Fish. Aquat. Sci. 210: 83-102

Morris, I., Skea, W. (1978). Products of photosynthesis in natural populations of marine phytoplankton from the Gulf of Maine. Mar. Biol. 47: 303-312

Myers, J. (1970). Genetic and adaptive physiological characteristics observed in the Chorellas. In: Prediction and measurement of photosynthetic productivity. Setlik, I. (ed.) (Proc. IBP/PP Technical Meeting, Trebon). Centre for Agricultural Publishing, Wogeninger, The Netherlands p. $447-454$

Myklestad, S. (1974). Production of carbohydrates by marine planktonic diatoms. I. Comparison of nine different species in culture. J. exp. mar. Biol. Ecol. 15: 261-274

Myklestad, S., Djurhuus, R., Mohus, A. (1982). Demonstration of exo-( $\beta-1,3)$-D-glucanase activity in some planktonic diatoms. J. exp. mar. Biol. Ecol. 56: 205-211

Prézelin, B. B. (1981). Light reactions in photosynthesis. In Platt, T (ed.) Physiological bases of phytoplankton ecology. Can. Bull. Fish. Aquat. Sci. 210: 1-43

Savidge, G. (1980). Photosynthesis of marine phytoplankton in fluctuating light regimes. Mar. Biol. Lett. 1: 295-300

Walsh, P., Legendre, L. (1983). Photosynthesis of natural phytoplankton under high frequency light fluctuations simulating those induced by sea surface waves. Limnol. Oceanogr. 28: 688-697 